\title{
Primary composition and diagenetic patterns of sandstones from Barra de Itiúba Formation in Atalaia High, Sergipe Sub-Basin
}

\author{
Composição primária e padrões diagenéticos dos arenitos da
} Formação Barra de Itiúba no Alto de Atalaia, Sub-bacia de Sergipe

Amanda Goulart Rodrigues ${ }^{1 *}$, Karin Goldberg ${ }^{1}$

\begin{abstract}
The petrologic analyses of 40 thin sections from two wells located in Atalaia High, offshore of Sergipe Sub-Basin, allowed the identification of primary composition and diagenetic patterns of Barra de Itiúba Formation. The original detrital compositions included arkoses, sublithic, and lithic sandstones. The main diagenetic processes observed were: compaction of metamorphic rock fragments and mud intraclasts, generating pseudomatrix; precipitation of quartz and feldspar overgrowths and outgrowths, cementation and grain replacement by kaolinite; dolomite and ferrous dolomite/ankerite; pyrite; iron oxides and hydroxides; and diagenetic titanium minerals, in addition to dissolution phases during eo-, meso- and telogenesis. The macroporosity in the two studied wells is primary intergranular, but there is secondary porosity due to dissolution of primary and diagenetic constituents, as well as fracture porosity. Thirteen reservoir petrofacies were defined and grouped into four reservoir petrofacies associations. They reflect the reservoir quality in microscale: good, medium and low-quality and non-reservoir. The good-quality is characterized by average total porosity greater than $15 \%$, whereas the medium shows average total porosity greater than $7 \%$. Lowquality presents average total porosity between 1 and $4 \%$, and the non-reservoir has an average total porosity consistently less than $1 \%$. Overall, the studied reservoirs consist on low-quality and non-reservoir rocks, which are intercalated with levels of mediumand good-quality. The loss of original porosity was mainly due to mechanical compaction (generating pseudomatrix), and cementation by kaolinite and dolomite. Preservation of primary porosity was favored by the presence of quartz overgrowths.
\end{abstract}

KEYWORDS: Reservoir Quality; Sergipe-Alagoas; Cretaceous; Diagenesis; Petrography.
RESUMO: As análises petrológicas de 40 lâminas em dois poços localizados no Alto de Atalaia, offshore da Sub-Bacia de Sergipe, permitiu a identificação das composiçôes primárias e dos padröes diagenéticos para a Formação Barra de Itiúba. As composiçōes detríticas originais das rochas são subarcósios, sublitarenitos e litarenitos. Os principais processos diagenéticos observados foram: compactação dos fragmentos de rocha metamórfica e intraclastos lamosos, formando pseudomatriz; precipitação de crescimentos e projeçōes de quartzo e feldspatos, cimentação e substituição por caulinita; dolomita e dolomita ferrosalanquerita; pirita; óxidos/hidróxidos de ferro e minerais de titânio diagenético, além de fases de dissolução eo-, meso-e telodiagenéticas. A macroporosidade dos dois poços estudados é predominantemente intergranular primária, porém há porosidade secundária por dissoluçáo de constituintes primários e diagenéticos como também porosidade por fratura. Treze petrofácies de reservatório foram definidas e sumarizadas em quatro associaçóes de petrofácies de reservatório. Elas refletem a qualidade dos reservatórios estudados em microescala: boa, média e baixa qualidade e não reservatório. A associação boa qualidade é caracterizada por apresentar porosidade total média acima de $15 \%$, enquanto que a média apresenta porosidade total média acima de 7\%. A associação de petrofácies de reservatório baixa qualidade tem porosidade média total entre 1 a 4\%, e a não reservatório possui porosidade total média inferior a 1\%. De modo geral, esses reservatórios consistem de baixa qualidade a não reservatório, intercalados com niveis de média e boa qualidade. A perda de porosidade original se deu principalmente por compactação mecânica (geraçáo de pseudomatriz) e cimentação de caulinita e dolomita. A preservação da porosidade primária foi favorecida pela presença de crescimentos secundários de quartzo.

PALAVRAS-CHAVE: Qualidade de Reservatório; Sergipe-Alagoas; Cretáceo; Diagênese; Petrografia.

\footnotetext{
${ }^{1}$ Geosciences Institute, Universidade Federal do Rio Grande do Sul - UFRGS, Porto Alegre (RS), Brasil. E-mails: rodriguesag.geo@gmail.com, karin.goldberg@ufrgs.br *Corresponding author
}

Manuscrito ID: 30110. Recebido em: 22/04/2014. Aprovado em: 07/10/2014. 


\section{INTRODUCTION}

Petrographic studies in sedimentary Brazilian basins are still scarce when compared to sedimentologic and stratigraphic ones, and the Sergipe-Alagoas Basin is not an exception. Previous works in the rift section regarding hydrocarbon exploration have focused on the sequence stratigraphy, sedimentology and interpretation of depositional systems (e.g. Barreiro 2004; Chiossi 2005; Borba et al. 2011). These tools are very important; however, they provide only macroscopic notions of reservoir qualities. Understanding the distribution of diagenetic alterations and their impact on the reservoir quality is a keystone in a petroleum field producer (Bloch 1994; Bloch \& Helmold 1995; Morad et al. 2000; Ketzer et al. 2003; Morad et al. 2010). According to Morad et al. (2010), variations in the pathways of diagenetic evolution are linked to: depositional facies, hence pore-water chemistry, depositional porosity and permeability, types and amounts of intrabasinal grains, and extent of bioturbation; detrital sand composition; rate of deposition (controlling residence time of sediments at specific near-surface and geochemical conditions); and burial thermal history of the basin. It is evident that diagenesis causes a complex deviation from the single progressive trend of declining porosity and permeability versus depth (Morad et al. 2000).

The aim of this study is the petrologic characterization of the primary texture, diagenetic processes, and pores types. Relations and intensity of these constituents have direct impact on porosity. Petrological data will allow the definition of reservoir petrofacies and inferences on quality of reservoir of the Barra de Itiúba Formation.

\section{GEOLOGICAL SETTING}

The Sergipe-Alagoas Basin is located in Brazil Northeastern (Fig. 1), along homonym states, with a NE elongated direction along $350 \mathrm{~km}$ of extension, between $9^{\circ}$ and $11^{\circ} 30^{\prime}$ South (Campos Neto et al. 2007). It is limited with the Parnaíba-Pernambuco Basin at North by the Maragogi High and with the Jacuípe Basin at South by the Vaza-Barris fault system (Feijó 1994). Its origin is associated with the breakup of Gondwana supercontinent in the Late Jurassic/ Early Cretaceous, which resulted in the formation of dozens of sedimentary basins in the Brazilian and African margins. The Sergipe-Alagoas Basin recorded all the rift phases, from pre-rift to drift strata and a thick sedimentary column (up to $10,000 \mathrm{~m}$ in the depocenter) deposited from Carboniferous to Quaternary.

The stratigraphy chart of Sergipe-Alagoas Basin was firstly organized by Schaller (1969), and later reviewed by
Feijó (1994) and Campos Neto et al. (2007). Barra de Itiúba Formation (K34-K36 sequences, correlated with Aratu until Lower Jiquiá local stage, sensu Campos Neto et al. 2007) was defined by the authors as deposits constituted of greenish-gray and black shales, interbedded with fine-grained sandstones and gravel-grained limestones. Moreover, the Barra de Itiúba Formation is characterized by lacustrine-deltaic deposits, while their proximal equivalents, gravel-grained sandstones of Penedo Formation, would be fluvial systems. Both are formed in the rift phase of the Sergipe-Alagoas Basin under a very active tectonic regime, and comprise the main reservoirs there. Galm and Santos (1994) recognized the pre-Aratu unconformity (DPA) within Barra de Itiúba Formation, a hiatus up to $5 \mathrm{My}$. Campos Neto et al. (2007) separated sediments under this unconformity (DPA) from Barra de Itiúba Formation and called them Feliz Deserto Formation (K10-K20 sequences, Rio da Serra stage). The studied wells belong to a petroleum offshore field located in Atalaia High, which was formerly encompassed in Aracaju High.

\section{METHODS}

Detailed petrographic analyses were carried out in 40 thin sections of two wells, provided by Petrobras UO-SEAL. The thin sections were prepared with blue epoxy-impregnated

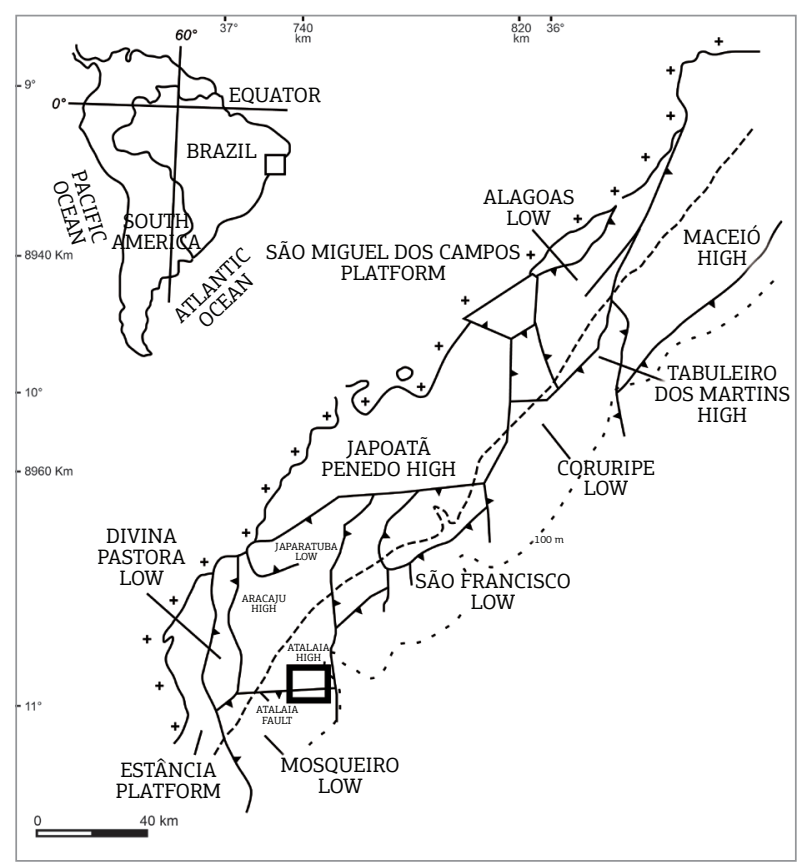

Figure 1. Structural map of the Sergipe-Alagoas Basin showing the configuration of the main normal faults, tectonic compartments, and localization of studies wells in the Atalaia High (modified from Garcia et al. 1990). 
samples, and the carbonate compositions stained with potassium ferricyanide plus Alizarin solution (Tucker 1988). Quantification of primary and diagenetic constituents and pore types was obtained by counting 300 points per section, using the Gazzi-Dickinson quantification method (cf. Zuffa 1985). Data were stored and processed in Petroledge software (De Ros et al. 2007).

The terms eogenesis, mesogenesis, and telogenesis are applied to the diagenetic stages sensu Morad et al. (2000). Eogenesis includes processes that happen under the influence of depositional fluids, at shallow depths and low temperatures (between 30 and $70^{\circ} \mathrm{C}$, about $2 \mathrm{~km}$ depth). Mesogenesis includes processes and reactions involving water formation under effective burial conditions and high relative temperature $\left(70\right.$ to $\left.-200^{\circ} \mathrm{C}\right)$. Shallow mesogenesis corresponds to depths between 2 and $3 \mathrm{~km}$ and temperatures between 70 and $100^{\circ} \mathrm{C}$, and the deep mesogenesis extends from depths around $3 \mathrm{~km}$ and temperatures around $100^{\circ} \mathrm{C}$ to the limit of metamorphism (temperatures higher than $200-250^{\circ} \mathrm{C}$ ), and to highly variable depths, depending on the thermal gradient of the area. Telogenesis refers to those processes related to the uplift and new exposure of sedimentary rocks to superficial conditions (near surface meteoric conditions). This causes a destabilizing of mesogenetic minerals and a new adaptation of the rock constituents in the new conditions.

The concept of reservoir petrofacies used in this paper is the same from De Ros and Goldberg (2007). This method consists into grouping samples according to the petrographic attributes that affect in reservoirs quality: texture, structure, types and bulk of primary and diagenetic constituents, and porosity.

\section{RESULTS}

\section{Structures, textures, and fabric}

The sandstones are very fine- to medium-grained (Fig. 2A), massive or with plane-parallel lamination defined by axis orientation of low-grade metamorphic fragments and mud intraclasts (Fig. 2B). Deformational structures include localized bioturbation and stylolites along carbonaceous fragments. Localized concretions and fractures, sometimes filled by dolomite or pyrite, may be also present. They are very poorly- to well-sorted, dominantly poorly sorted (Fig. 2C); angular to rounded, mainly sub-rounded; with low sphericity. Presence of quartz overgrowths and compaction of soft clasts (lowgrade metamorphic rock fragments and mud intraclasts) may modify the roundness in some samples. Grain orientation is chaotic or sub-parallel.

\section{Primary composition}

The original composition is mostly lithic, with sublitharenites, litharenites, subarkoses, and rarely quartzarenites (sensu Folk 1968; Fig. 3). Primary composition was slightly modified by diagenetic processes, such as the kaolinization of feldspar and low-grade metamorphic fragments, resulting in more quartzose compositions. The two studied wells do not show substantial differences in composition (Well $A=Q_{66} F_{6} L_{28}$ and $\mathrm{B}=\mathrm{Q}_{69} \mathrm{~F}_{6} \mathrm{~L}_{25}$ ), although Well $\mathrm{B}$ has a tendency for subarkose to feldspathic composition.

Quartz grains are dominantly monocrystalline (average: 34\%; maximum: 61\%, Fig. 2C) and polycrystalline (average: 2\%; maximum: 10\%). Orthoclase is the only feldspar present (average: 2\%; maximum: 6\%), and it is commonly replaced by kaolinite.

Lithic fragments are abundant, mainly of low-grade metamorphic rocks (Fig. 2D) like slate (average: 3\%; maximum: $12 \%$ ), phyllite (average: 1\%; maximum: 6\%), meta-siltstone (average: 5\%; maximum: 17\%), and meta-sandstones (average: 1\%; maximum: 7\%). Sedimentary rock fragments are less common, including chert (average: 2\%; maximum: 7\%), mudstones (average: < 1\%; maximum: $1 \%$ ), sandstones (average: $<1 \%$; maximum: $2 \%$ ), and siltstones (average: $\leq 1 \%$; maximum: 3\%). Plutonic rock fragments are rare $(<1 \%)$.

Muscovite (average: < 1\%; maximum: 3\%, Fig. 2E) occurs as monocrystalline grains and in sedimentary and metamorphic fragments. Zircon, tourmaline, and rutile are less common (together, average: $<1 \%$; maximum: $2 \%$ ).

Intrabasinal constituents are mud and argillaceous intraclasts (average: 2\%; maximum: 11\%, Fig. 2F). They are generally deformed by mechanical compaction and sometimes replaced by kaolinite. Carbonate bioclasts are rare, replaced and recrystallized by dolomite/ferrous dolomite and ankerite. An ostracod-rich layer (5\%) was found only at the depth of $1872.60 \mathrm{~m}$ in Well B. Phosphatic and siliceous bioclasts rarely occur. In fine-grained sandstones and lutites, may occur some argillaceous bioturbation matrix (average: 2\%; maximum: 58\%).

\section{Diagenetic constituents}

The diagenetic processes and their products identified in the studied rocks are: compaction of metamorphic rocks fragments and intraclasts forming pseudomatrix; quartz and feldspar (albite and K-feldspar) overgrowth and outgrowth; cementation and replacement by kaolinite, and precipitation of dolomite and ferrous dolomite to ankerite; pyrite; iron oxides and hydroxides; and titanium diagenetic minerals. Wells A and B have similar characteristics, thus the results will be showed together. Nevertheless, there are differences in the sequence and intensity of diagenetic processes. Therefore, two diagenetic models will be proposed (see "Discussion" item). 

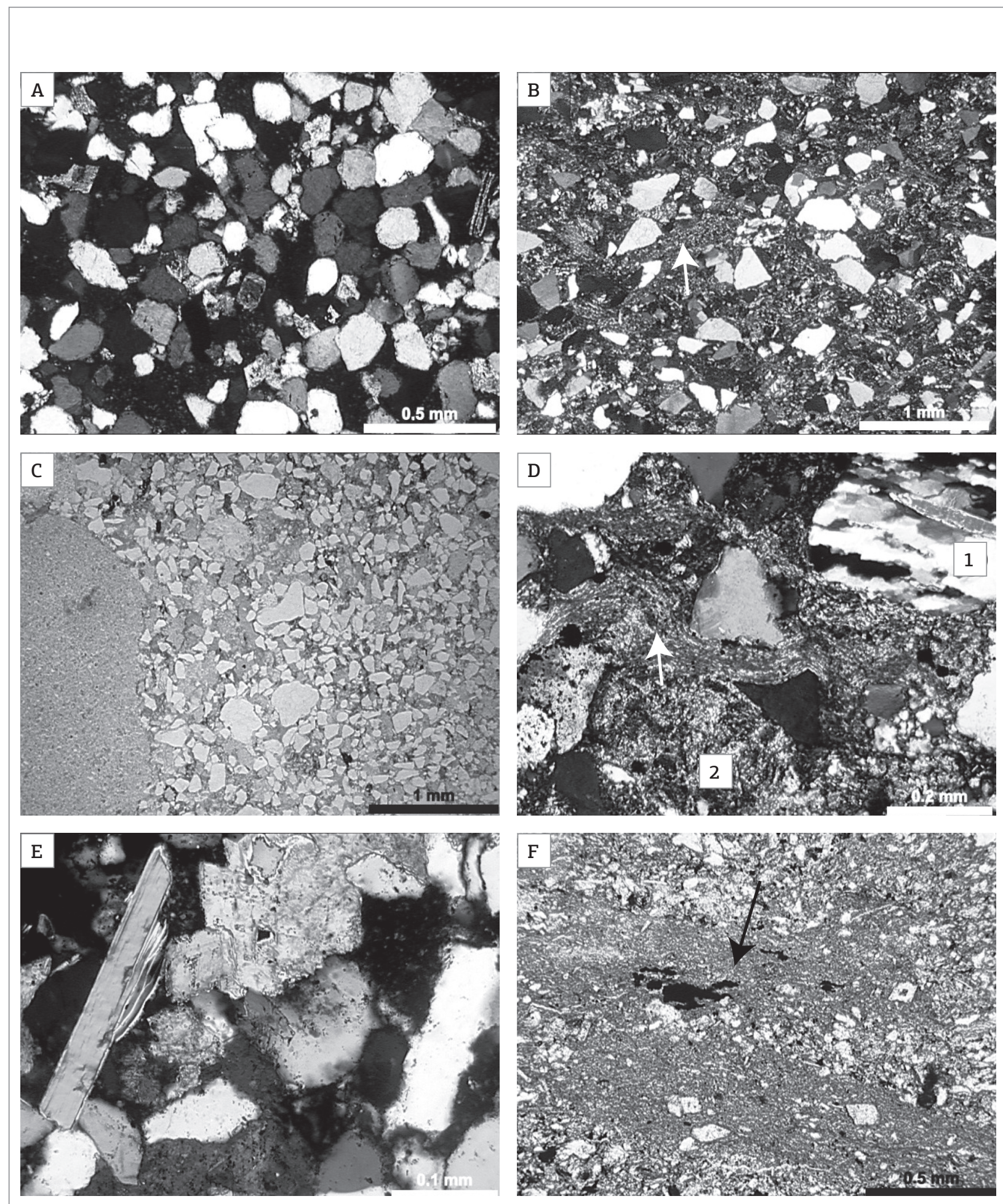

Figure 2. Structural, textural, and compositional aspects of the studied samples: (A) Very fine-grained, well-sorted, massive sandstone (crossed polarizers, XP); (B) Plane-parallel lamination defined by axis orientation of low-grade metamorphic fragments (arrow, XP); (C) Very fine-grained, very poorly-sorted, massive sandstone (uncrossed polarizers, //P); (D) Phyllite (arrow), gneiss (1) and meta-sandstone (2, XP) fragments; (E) Muscovite (XP); (F) Mud argillaceous intraclasts (arrow, //P). 


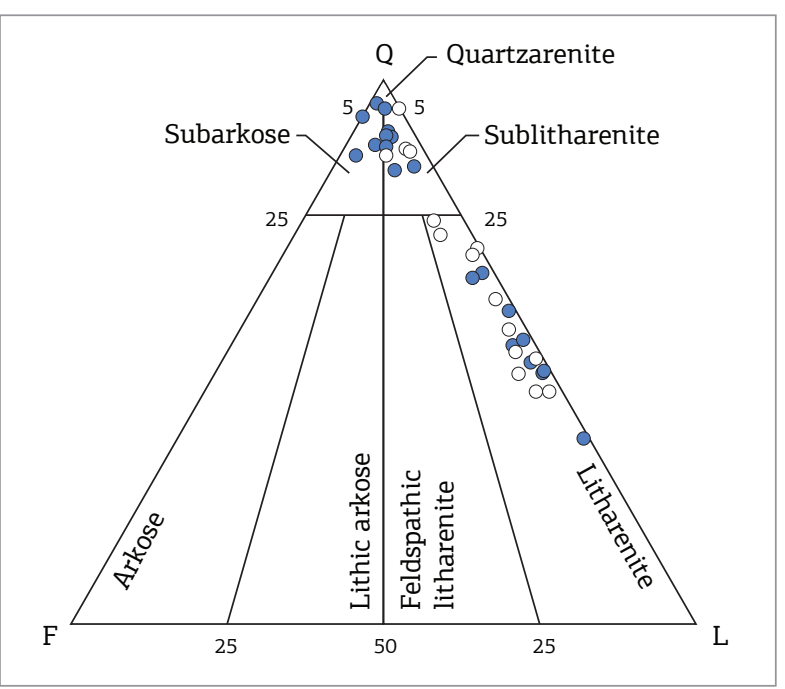

Figure 3. Detrital composition of sandstones plotted in Folk (1968) diagram. White circles are samples from Well $\mathrm{A}$ and gray circles from $\mathrm{B}$.

The origin of pseudomatrix is related to compaction of mud intraclasts (argillaceous pseudomatrix, average: 2\%; maximum: 13\%, Fig. 4A) and low-grade metamorphic fragments (lithic pseudomatrix, average: 2\%; maximum: 18\%), as in Fig. 4B.

Quartz occurs as continuous and discontinuous overgrowths and outgrowths on monocrystalline and polycrystalline quartz grains (average: $4 \%$; maximum: $13 \%$ ). It engulfs kaolinite (Fig. 4C), dolomite, pseudomatrix and diagenetic clay. There are rare discrete quartz crystals $(<1 \%)$.

Discontinuous (sometimes continuous) albite and $\mathrm{K}$-feldspar overgrowths are rare $(<1 \%)$. Albite overgrowths cover orthoclase and plagioclase, and microcrystalline albite replaces orthoclase. Discrete albite crystals were found only at the depth of $2094.30 \mathrm{~m}$ in Well A. The K-feldspar overgrowths cover only orthoclase.

Kaolinite is present in all studied samples as booklets, lamellar and vermicular forms (Fig. 4D), replacing orthoclase (average: $1 \%$; maximum: 6\%), chert, muscovite (average: $1 \%$; maximum: $6 \%$ ), low-grade metamorphic rock fragments (average: $3 \%$; maximum: $12 \%$ ), lithic pseudomatrix (average: $<1 \%$; maximum: $2 \%$ ), and argillaceous matrix (average: $<1 \%$; maximum: 5\%). Furthermore, booklets and lamellar aggregates replace argillaceous intraclasts (average: 3\%; maximum: 12\%) and mud pseudomatrix (average: 3\%; maximum: 7\%). Lamellar kaolinite generally expanded and replaced muscovite, indicating early precipitation. Kaolinite also fills primary pores (average: 1\%; maximum: 5\%), causing porosity reduction.
Dolomite is the main diagenetic constituent, replacing primary constituents (average: 10\%; maximum: 41\%), kaolinite (average: 3\%; maximum: 11\%), authigenic quartz (average: $<1 \%$; maximum: 3\%), and mud pseudomatrix (average: $<1 \%$; maximum: $4 \%$ ). Dolomite also fills primary and fracture pores (average: 1\%; maximum: 10\%). Dolomite habits include macrocrystalline, fine and coarse mosaic, poikilotopic crystals, as well as large and small rhombs and saddle dolomite. The chemical composition varies between dolomite, ferrous dolomite, and ankerite. Crystal zonation is common in Well A, with ankerite in the core and dolomite in rhomb margins (Fig. 4E).

Pyrite occurs as framboids, macrocrystalline and blocky crystals (Fig. 4F), replacing primary constituents (average: $<1 \%$; maximum: $3 \%)$, pseudomatrix $(<1 \%)$, and dolomite and ferrous dolomite/ankerite (average: $<1 \%$; maximum: $4 \%$ ). Rarely pyrite fills primary and fracture pores $(<1 \%)$.

Microcrystalline iron oxides and hydroxides coatings delimit the grain boundaries regarding quartz overgrowths (Fig. 4A). Their occurrence is inexpressive $(<1 \%)$, except for one sample in Well B at $1825.70 \mathrm{~m}$ (3\%). They replace detrital constituents (quartz, slate fragments, and mud intraclasts) and diagenetic constituents (kaolinite, dolomite and argillaceous pseudomatrix), and fill primary pores.

Diagenetic titanium minerals $(<1 \%)$ display blocky, macrocrystalline, prismatic, and microcrystalline forms. Those constituents replace detrital quartz, phyllite fragments, kaolinite, dolomite, and argillaceous pseudomatrix.

Jarosite, gypsum, bitumen and paraffinic hydrocarbon are present in the studied rocks. Gypsum fills pores and it is partially dissolved (only in Well B at 1853.85 m). Bitumen covers monocrystalline quartz and several fragments. Paraffinic hydrocarbon fills primary pores. All these constituents occur in low expression $(<1 \%)$.

\section{Porosity and compaction}

The macroporosity is mainly primary intergranular (average: $4 \%$; maximum: $19 \%$, Fig. $5 \mathrm{~A}$ ), but there is secondary porosity by dissolution and rock and/or grain fractures. The primary constituents dissolved (Figs. 5B to 5D) are low-grade metamorphic rock fragments (slate, phyllite, meta-siltstone and meta-sandstones), chert, mud-argillaceous intraclasts, monocrystalline quartz and orthoclase, and siliciclastic matrix of bioturbation. The dissolved diagenetic constituents include argillaceous pseudomatrix and kaolinitized grains. Fracture porosity is more common in mud argillaceous intraclasts (average: $<1 \%$; maximum: $3 \%$ ). There are excavation pores in some samples due to a located bioturbation (Fig. 5E). 

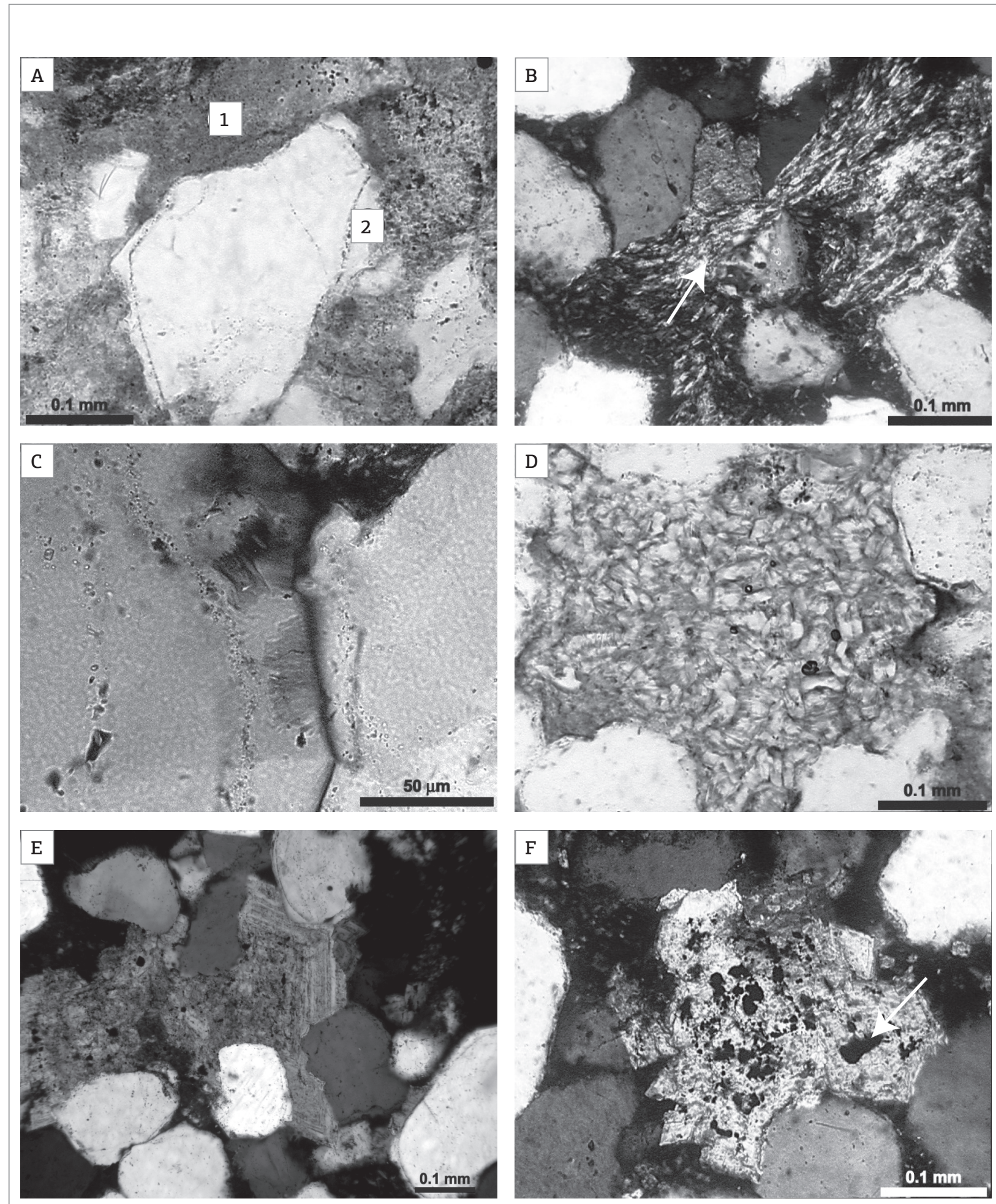

Figure 4. Diagenetic aspects from the Barra de Itiúba Formation: (A) Argillaceous pseudomatrix (1) and quartz overgrowths (2, plane polarizers //P); (B) Lithic pseudomatrix (arrow, crossed polarizers XP); (C) Discontinuous quartz overgrowths engulfing kaolinite (XP); (D) Kaolinite booklets replacing indeterminate primary constituent (//P); (E) Crystal zonation with ankerite in the core and dolomite in rhomb margins (XP); (F) Framboidal pyrite replacing blocky dolomite (arrow, XP). 

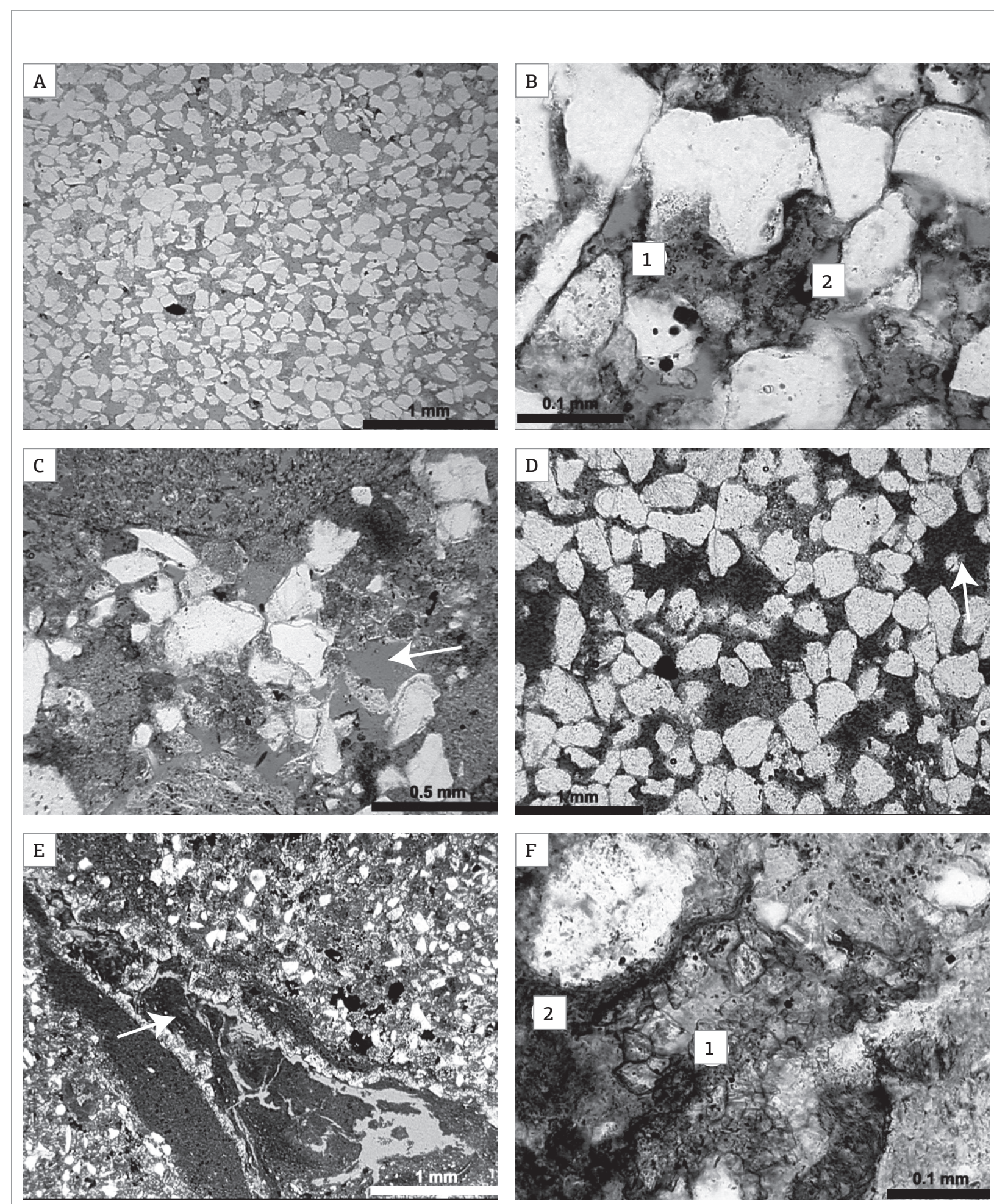

Figure 5. Types of macroporosity: (A) Primary porosity widely preserved; (B) Porosity of pseudomatrix dissolution (1) and moldic (2); (C) Moldic porosity (arrow); (D) Secondary porosity of quartz dissolution (arrow); (E) Excavation pore (arrow); (F) Primary porosity is obliterated by dolomite rhomb (1) and argillaceous pseudomatrix (2). All photomicrographs were taken with uncrossed polarizers (//P). 
The fabric of most samples are normal, rarely tight, or loose. Sandstones exhibit mechanical compaction, and locally chemical compaction (e.g. levels of stylolitization). The percentage of primary porosity loss due to compaction versus cementation may be represented in Ehrenberg's diagram (1989, Fig. 6), which reports the intergranular

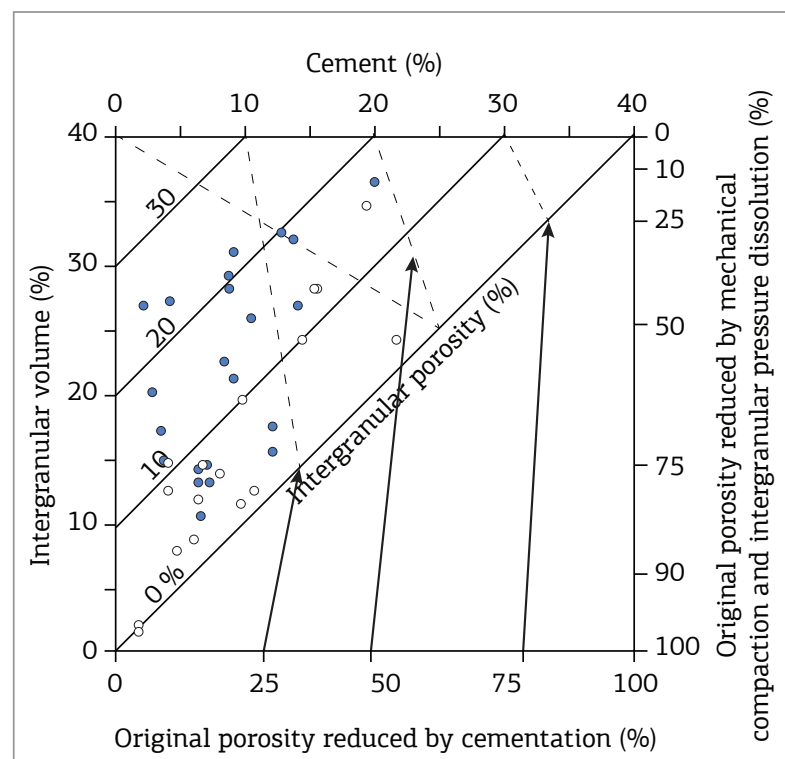

Figure 6. Ehrenberg (1989) diagram showing the relationship between intergranular volume and total cement, correlating the primary porosity reduction with cementation and/or compaction. White circles are samples from Well A, and gray ones from $\mathrm{B}$. volume (IGV) with cement percentage, accepting $40 \%$ of the initial porosity (depositional; Worden \& Burley 2003). Intergranular porosity values in the diagram are overestimated for the samples analyzed because initial porosity is smaller than $40 \%$ due to poor particle selection.

Nevertheless, Ehrenberg's (1989) diagram indicates that original porosity was obliterated mainly by mechanical compaction, not by cementation. Sandstones from Well A were more affected by mechanical compaction than the ones from Well B, due to the greater amount of ductile fragments, such as intraclasts and low-grade metamorphic fragments. This resulted in a lower intergranular porosity in Well A (up to $10 \%$, except for two samples). Samples from Well $\mathrm{B}$ are more porous (up to $20 \%$ ). In addition to mechanical compaction, intergranular porosity loss also happened due to kaolinite and dolomite cementation, as well as pseudomatrix generation (Fig. 5F).

\section{Reservoir petrofacies associations}

Thirteen reservoir petrofacies, identified based on petrography data, were summarized in four reservoir petrofacies associations (Tab. 1). They possibly reflect the real reservoir quality in microscale: good-, medium- and low-quality and non-reservoir. Fig. 7 shows a representative set of photomicrographs from reservoir groups.

The good-quality petrofacies association (Fig. 7A) consists of fine- to medium-grained sandstones, well to moderately sorted, with a quartzose primary composition (sublitharenites, quartzarenites and subarkoses), and rare mud intraclasts $(<2 \%)$ and pseudomatrix $(<3 \%)$. The total cementation

Table 1. Averages and maximum of main constituents and porosities to reservoir petrofacies defined for the Barra de Itiúba Formation.

\begin{tabular}{|c|c|c|c|c|c|c|c|c|c|c|c|c|c|c|c|c|c|c|c|c|c|c|c|c|c|c|}
\hline \multirow{3}{*}{$\begin{array}{l}\text { Reservoir Petrofacies } \\
\text { Associations } \\
\text { Composition/ } \\
\text { Petrofacies } \\
\begin{array}{l}\text { Constituents and } \\
\text { porosities }\end{array} \\
\end{array}$} & \multirow{2}{*}{\multicolumn{2}{|c|}{$\begin{array}{c}\begin{array}{c}\text { Good- } \\
\text { quality }\end{array} \\
1\end{array}$}} & \multirow{2}{*}{\multicolumn{2}{|c|}{\begin{tabular}{|c|} 
Medium- \\
quality
\end{tabular}}} & \multicolumn{10}{|c|}{ Low-quality } & \multicolumn{12}{|c|}{ Non-reservoir } \\
\hline & & & & & \multicolumn{2}{|c|}{3} & \multicolumn{2}{|c|}{4} & \multicolumn{2}{|c|}{5} & \multicolumn{2}{|r|}{6} & \multicolumn{2}{|c|}{7} & \multicolumn{2}{|c|}{8} & \multicolumn{2}{|r|}{9} & \multicolumn{2}{|c|}{10} & \multicolumn{2}{|c|}{11} & \multicolumn{2}{|c|}{12} & \multicolumn{2}{|c|}{13} \\
\hline & Av. & Max. & Av. & Max. & Av. & Max. & Av. & Max. & Av. & Max. & Av. & Max. & Av. & Max. & Av. & Max. & Av. & Max. & Av. & Max. & Av. & Max. & Av. & Max. & Av. & Max. \\
\hline Total intraclasts & 1.25 & 2 & 1.58 & 3.67 & 2.5 & 3.67 & 2.5 & 5 & 2.33 & 2.33 & 0.5 & 1 & 0.17 & 0.33 & 1 & 1 & 0.72 & 3 & 6.89 & 11 & 2.42 & 5.67 & 0 & 0 & 0.11 & 0.33 \\
\hline Total cement & 13.8 & 20 & 11.4 & 19.3 & 6.17 & 8.33 & 5.5 & 6.33 & 15.3 & 15.3 & 5.17 & 6.33 & 6 & 12 & 2 & 2 & 9 & 21.7 & 3.22 & 3.67 & 6.75 & 12 & 0 & 0 & 8.78 & 10.7 \\
\hline Total matrix & 0 & 0 & 0 & 0 & 0 & 0 & 0 & 0 & 3.67 & 3.67 & 0 & 0 & 0.5 & 1 & 0 & 0 & 0.11 & 0.67 & 0 & 0 & 0 & 0 & 28.7 & 57.3 & 0.22 & 0.67 \\
\hline Total pseudomatrix & 1.5 & 3 & 2.42 & 5.67 & 9.84 & 12.7 & 1.5 & 2.33 & 1 & 1 & 3.33 & 5.33 & 0 & 0 & 18.3 & 18.3 & 0.44 & 1.67 & 8.45 & 13.3 & 1.41 & 3.66 & 0 & 0 & 2.78 & 6.67 \\
\hline Total kaolinite & 9.58 & 16.3 & 13.6 & 18 & 13.2 & 14.7 & 17 & 19.3 & 14.3 & 14.3 & 19.2 & 23 & 1.83 & 3.66 & 10.7 & 10.7 & 10.6 & 17.3 & 14 & 18.7 & 10.7 & 14.7 & 4.01 & 8.01 & 11.9 & 12.7 \\
\hline $\begin{array}{l}\text { Dolomite }+ \text { total } \\
\text { ferrous dolomite }\end{array}$ & 2.16 & 8.65 & 7.45 & 12.7 & 11.5 & 13.7 & 4.82 & 5.99 & 14 & 14 & 0.99 & 1.32 & 22.8 & 45.7 & 17.7 & 17.7 & 33.7 & 58 & 3.32 & 4.31 & 22.6 & 33 & 2.84 & 5.67 & 24.7 & 36 \\
\hline $\begin{array}{l}\text { Total authigenic } \\
\text { quartz }\end{array}$ & 8.83 & 13.3 & 6.46 & 14.3 & 2.66 & 2.67 & 3.17 & 3.67 & 5.67 & 5.67 & 3 & 3.66 & 0.17 & 0.33 & 1.67 & 1.67 & 3.05 & 5 & 3.22 & 3.66 & 2.67 & 4.68 & 0 & 0 & 5.44 & 8.33 \\
\hline $\begin{array}{l}\text { Intergranular kaolinite } \\
\text { / total kaolinite }\end{array}$ & 0.52 & 0.86 & 0.26 & 0.35 & 0.37 & 0.4 & 0.14 & 0.17 & 0.4 & 0.4 & 0.15 & 0.19 & 0 & 0 & 0.03 & 0.03 & 0.24 & 0.43 & 0.24 & 0.45 & 0.3 & 0.7 & 0.1 & 0.21 & 0.24 & 0.45 \\
\hline $\begin{array}{l}\text { Intergranular dolomite } \\
\text { / total dolomite }\end{array}$ & 0.14 & 0.58 & 0.43 & 0.72 & 0.47 & 0.57 & 0.16 & 0.27 & 0.6 & 0.6 & 0 & 0 & 0.15 & 0.31 & 0.3 & 0.3 & 0.15 & 0.3 & 0.26 & 0.46 & 0.19 & 0.3 & 0.44 & 0.88 & 0.06 & 0.11 \\
\hline $\begin{array}{l}\text { Ductile grains + total } \\
\text { pseudomatrix }\end{array}$ & 4.17 & 6 & 7.25 & 9.67 & 16.8 & 19 & 22.7 & 22.7 & 8 & 8 & 23.5 & 26 & 6.33 & 12.7 & 32.7 & 32.7 & 11.9 & 21.3 & 32.2 & 45 & 21.8 & 26.3 & 1.83 & 3.67 & 22.3 & 30.7 \\
\hline Total porosity & 17.4 & 19 & 7.92 & 9.33 & 1.67 & 2.33 & 4.66 & 5.33 & 2.99 & 2.99 & 5.83 & 5.99 & 2.99 & 5.99 & 0.66 & 0.66 & 1.44 & 5 & 0.33 & 0.66 & 0.75 & 1.66 & 1.16 & 2.33 & 0.89 & 1.34 \\
\hline $\begin{array}{l}\text { Intergranular porosity } \\
\text { / total porosity }\end{array}$ & 0.92 & 0.98 & 0.88 & 0.92 & 0.69 & 0.72 & 0.24 & 0.31 & 0.89 & 0.89 & 0.43 & 0.45 & 0.44 & 0.89 & 0.5 & 0.5 & 0.51 & 1 & 0.17 & 0.5 & 0.3 & 1 & 0 & 0 & 0.08 & 0.25 \\
\hline
\end{tabular}


in these rocks are up to $20 \%$, composed mainly of quartz (3 to $13 \%)$, kaolinite (2 to $17 \%$ ), and pyrite $(<1 \%)$. Kaolinite and dolomite replace primary and diagenetic constituents. The primary intergranular porosity is preserved, and secondary one was generated by grain dissolutions (total porosity, from 14 to $17 \%$ ).

The medium-quality petrofacies association (Fig. 7B) comprises fine- and muddy fine-grained sandstones, well to very poorly sorted, with a feldspar-lithic primary composition (subarkoses, sublitharenites, feldspathic litharenites). Presence of intraclasts (up to $4 \%$ ) and pseudomatrix (up to 6\%) is significant. Total cement is up to $19 \%$, with quartz ( 4 to $15 \%$ ), kaolinite (1 to $8 \%$ ), and dolomite (0 to $10 \%$ ). Kaolinite and dolomite may also replace primary and diagenetic constituents. Primary intergranular porosity is partially preserved, and secondary porosity happens due to grain dissolution. Average total porosity is $8 \%$, with a maximum of $11 \%$.
The low-quality petrofacies association (Fig. 7C) consists of siltstones and very fine- to medium-grained sandstones, well to poorly sorted, with a feldspar-lithic primary composition (litharenites, sublitharenites, and subarkoses), with abundant mud intraclasts (up to 5\%) and pseudomatrix (up to 13\%). Total cement is up to $15 \%$, with quartz (2 to $4 \%$ ), kaolinite (0 to $5 \%$ ) and dolomite (0 to $14 \%$ ). Kaolinite and dolomite replace primary and diagenetic constituents. Primary porosity is rare, largely obliterated by pseudomatrix and dolomite. Minor secondary porosity resulted from grain dissolution. Average total porosity is $4 \%$, with a maximum of $6 \%$.

The non-reservoir petrofacies association (Fig. 7D) consists of very fine- to medium-grained sandstones and lutites, very poor or poorly sorted, with a feldspar-lithic primary composition (litharenites, subarkoses and sublitharenites) sometimes with abundant matrix (up to 57\%), stylolites, incipient bioturbation, argillaceous intraclasts (up to 7\%), and pseudomatrix (up to $23 \%$ ). Total cement is up to $22 \%$,
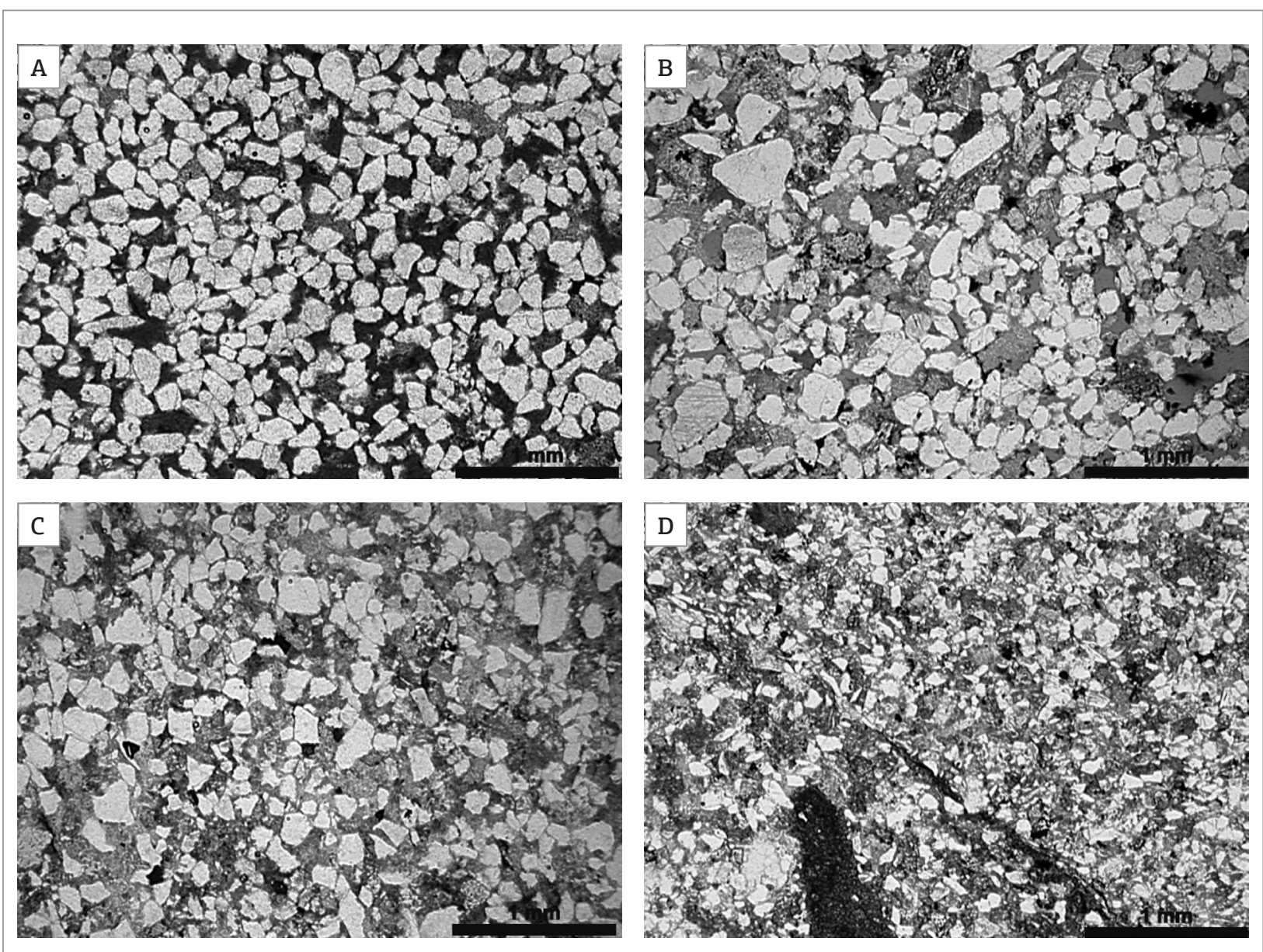

Figure 7. Reservoir petrofacies associations identified in the Barra de Itiúba Formation, based on petrological data. Photomicrographs of each association were taken with uncrossed polarizers. (A) Good-quality; (B) Mediumquality; (C) Low-quality; (D) Non-reservoir. 
with quartz $(1-9 \%)$ and dolomite $(1-14 \%)$. Kaolinite and dolomite replace primary and diagenetic constituents. All the porosity is secondary, from grain dissolution and fracturing (average total porosity is of $1 \%$, with a maximum of $5 \%$ ).

The good-quality reservoir petrofacies association is characterized by average total porosity above $15 \%$, whereas the medium association presents average total porosity above $7 \%$. In these associations, the dominant porosity is intergranular (intergranular porosity/total porosity $>0.80$ ). The low-quality petrofacies associations display average total porosity between 1 and $4 \%$, and the non-reservoir $<1 \%$. Fig. 8 presents the relationship between macroporosity and depth for the studied samples, according to the reservoir quality. The reservoir petrofacies associations retain their porosities with increasing depth. Only in Well A, samples classified as non-reservoir display a small increase in porosity with depth, probably due to an increase in the secondary porosity. Overall, there is not a difference in porosity between Wells A and B as to depth.

\section{DISCUSSION}

The paragenetic sequences were constructed from textural relations between primary and diagenetic constituents using a conventional optical microscopy. Two diagrams (Fig. 9) were presented for litharenites/sublitharenites and subarkoses, since the intensity of diagenetic processes are different for these compositions (De Ros 1996). These diagrams illustrate the paragenetic sequences and main processes in each diagenetic stage.

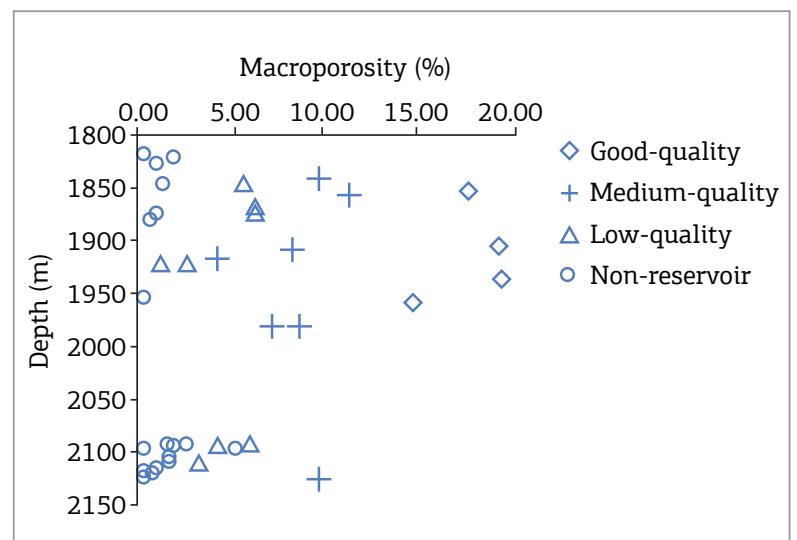

Figure 8. Relationship between macroporosity (\%) and depth $(\mathrm{m})$. The macroporosity is preserved with increasing depth. In Well A there is an increase in the secondary porosity due to dissolution of constituents and fractures. The samples are presented in their respective reservoir petrofacies associations.

\section{Summary model of diagenetic evolution}

Eogenetic alterations exert a substantial control on the deep-burial, mesogenetic evolution of the sandstones (Morad et al. 2000; 2010), because burial diagenesis will be constrained by the extent of fluid flow through the remaining porosity and influenced by the presence of earlier diagenetic products to affect. Eogenetic processes observed in this study include the dissolution of primary constituents, replacement and cementation by kaolinite, ferrous oxides and hydroxides, quartz overgrowths, dolomite and pseudomatrix generation.

Under warm, subhumid to humid conditions (precipitation $>1,000 \mathrm{~mm} \mathrm{yr}^{-1}$ ) and in proximal fluvial sediments, active percolation of undersaturated meteoric waters cause the dissolution of detrital silicates (primarily lithic grains, feldspar and mica), and precipitation of kaolinite (Morad et al. 2000). Kaolinized micas generally show expanded textures (Ketzer et al. 2003; Morad et al. 2010), which is an indication of happening before significant compaction. Ferrous oxides and hydroxides precipitated as coatings over this diagenetic phase, while there was in contact with oxidizing surface waters, typical of continental, humid environments. The silica enrichment in solution due to the dissolution of feldspar and lithic fragments allowed the precipitation of quartz as overgrowths. Authigenic quartz began to precipitate in eogenesis (continuous overgrowths, McBride 1989; Bjørlykke \& Egeberg 1993; Giles et al. 2000; Milliken 2005), proceeding during mesogenesis as prismatic projections and discontinuous overgrowths (Morad et al. 2000).

Mechanical compaction was more intense in lithic/ sublithic sandstones because of the abundance of ductile fragments, mostly low-grade metamorphic rock fragments, generating argillaceous pseudomatrix. Mechanical compaction was not significant in the subarkose sandstones due to fabric stabilization given by precipitation of quartz overgrowths and by the minor quantity of low-grade metamorphic rock fragments and intraclasts.

Two phases of dolomitization were observed, one in eogenesis and another in mesogenesis. The first, less expressive, was interpreted from the paragenetic relation with quartz overgrowths, since the latter engulfs and then is replaced by dolomite. Extensive cementation by dolomite as eogenetic processes in lacustrine deltas is reported by Pitman et al. (1986), Anjos et al. (2000), and Luo et al. (2009). The second stage of dolomitization is marked through the cementation and replacement of primary constituents by ferrous dolomite (sometimes ankerite), and non-ferrous dolomite occurred due to a change in the interstitial fluid composition to more alkaline and reduced terms. This appeared in the lithic/sublithic sandstones as a zonation in dolomite rhombs, with display ankeritic core and magnesium-rich rims. 
PARAGENETIC MODELS
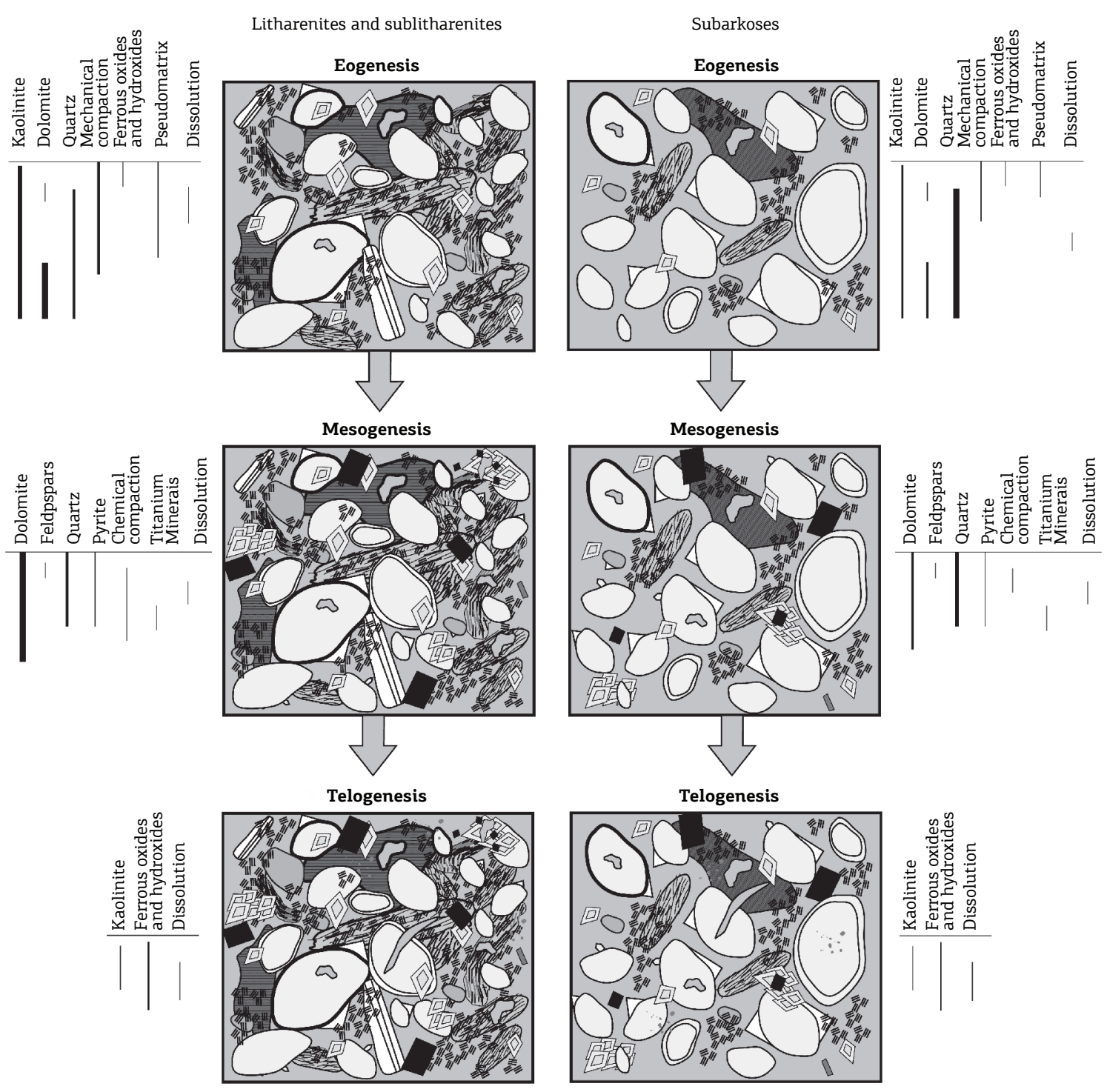

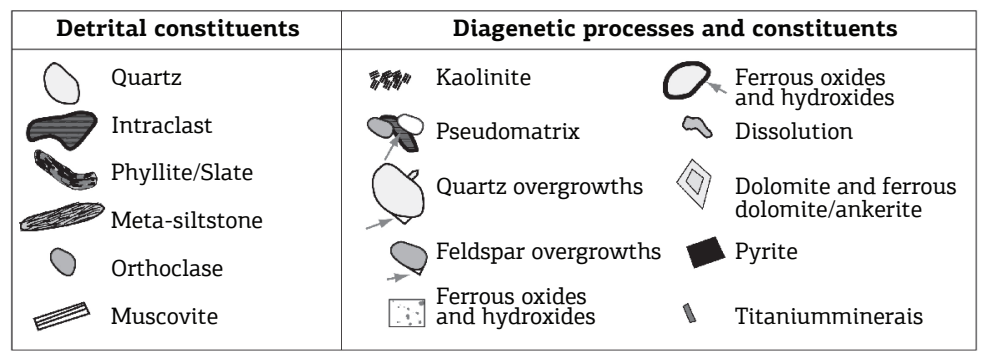

Figure 9. Paragenetic models to the Barra de Itiúba Formation with paragenetic order of diagenetic processes for each primary composition (Litharenites/Sublitharenites and Subarkoses). 
Mesogenesis is strongly influenced by induced eogenetic alterations, as well as by temperature, pressure, and composition in basinal brines (Morad et al. 2010). Continuous burial led to mechanical and chemical compaction in advanced stages, evidenced by levels of stylolitization, false contacts between muscovite and other primaries constituents, and sutured contacts (Morad et al. 2000). The instability between interstitial fluids and primary and diagenetic constituents resulted in several dissolution phases during every diagenetic stage.

Pyrite precipitation occurred associated with dolomite, also as a grain-replacive constituent. It was related to fluids enriched in $\mathrm{H}_{2} \mathrm{~S}$ derived from thermal sulfate reduction (Machel 1987). The formation of diagenetic titanium minerals occurred as a result of Ti-enrichment in the interstitial solutions by dissolution of detrital heavy minerals. There was also precipitation of discontinuous K-feldspar and albite overgrowths (Saigal et al. 1988; Morad et al. 1990) in this stage.

The exposure of rocks to conditions of surface waters during telogenesis destabilized the mineral assemblage, resulting in dissolution of primary and diagenetic constituents. Local precipitation of iron oxides and hydroxides, kaolinite, jarosite and gypsum was a product of fluid percolation. Jarosite $\left(\mathrm{KFe}_{3}{ }^{+3}\left(\mathrm{SO}_{4}\right)^{2}(\mathrm{OH})_{6}\right)$ is a product of hydration and oxidation of pyrite in conditions of local hidrothermalism or telogenesis.

\section{Differential diagenetic patterns}

The main difference between diagenetic patterns for subarkoses and litharenites/sublitharenites is that the subarkoses display a larger quantity of quartz overgrowths. Consequently, mechanical compaction for subarkoses was not significant due to fabric stabilization given by precipitation of quartz overgrowths and minor quantity of low-grade metamorphic rock fragments and intraclasts. This compositional distinction leads to a different intensity of diagenetic processes. A reflection of this is the replacement and cementation by dolomite to ferrous dolomite/ankerite considerably less intense than in the litharenites and sublitharenites.

\section{Provenance}

The original feldspar-lithic detrital composition indicates a provenance from orogenic recycling (sensu Dickinson 1985; Fig. 10). The more quartz-feldspathic composition in Well B may reflect a change of provenance, with a contribution of cratonic interior source. The low-grade metamorphic lithic fragments may come from Proterozoic basement of the Miaba and Vaza-Barris Group (Moraes Rego 1933). The dolomite fragments that were founded possibly come from Cambrian meta-sedimentary rocks from the Estância Group (Silva et al. 1978), basement of the Sergipe Sub-Basin.
Some thin sections suggested a cratonic interior provenance. It was not possible to identify a compositional pattern with systematic variation in provenance either in Wells A or B. Therefore, the presence of more quartzose terms may be related to autocyclic controls in the depositional environment, related to a longer-distance transport (and consequent deterioration of lithic fragments).

In compositional terms, the studied samples are very different from those of Becker (1987). The average composition of Becker (1987) is arkoses; while of the studied samples are lithic sandstones $\left(\mathrm{Q}_{66} \mathrm{~F}_{6} \mathrm{~L}_{28}\right.$ and $\mathrm{Q}_{69} \mathrm{~F}_{6} \mathrm{~L}_{25}$, in Wells A and B, respectively). The analyzed samples are similar in terms of detrital and diagenetic composition to the Carmópolis Formation (Souza et al. 1995). However, the studied interval was positioned stratigraphically and correlated through ostracod biozones (data from Petrobras), which should provide a good biostratigraphic position to studied interval.

\section{Impact of diagenetic constituents in reservoir quality}

Petrographic analysis has showed that reservoir quality is mostly impacted by diagenetic processes (Morad et al. 2010). Depositional texture does not vary significantly, since all studied rocks are fine-grained (siltstones and fine-grained sandstones). Loss of porosity occurred due to pseudomatrix generation (a product of mechanical compaction), and kaolinite and dolomite cementation. Thus, detrital composition has a considerable influence

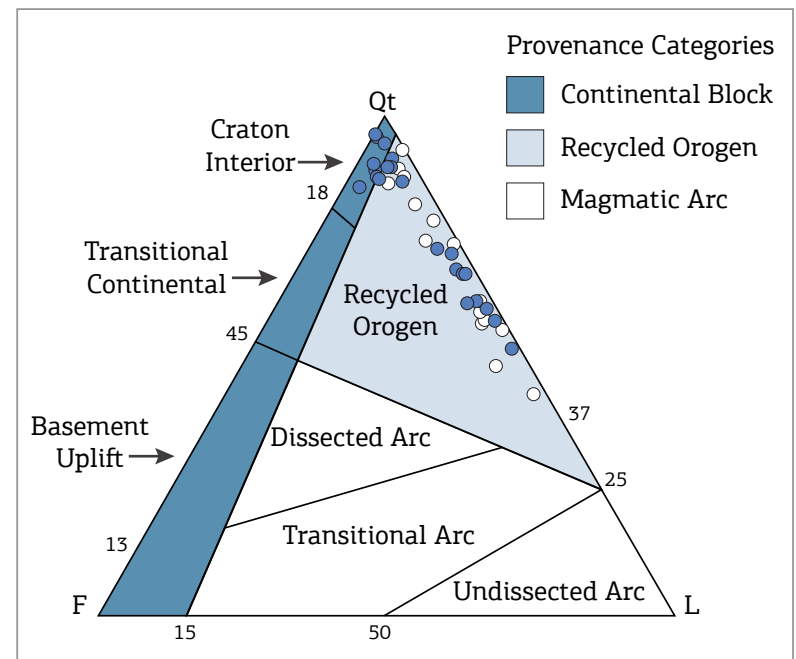

Figure 10. The provenance Dickinson I diagram (Dickinson 1985), showing the main contribution of recycled orogen provenance and subordinate contribution of craton interior to the Well $\mathrm{B}$. White circles are samples from Well A, gray ones from B. 
on porosity reduction: sandstones with more contents of lithic fragments displayed high porosity reduction by mechanical compaction. On the other hand, sandstones with more feldspar and intraclasts showed generation of secondary porosity by dissolution of these constituents. In some petrofacies (low-quality and non-reservoir), there was an important creation of secondary porosity by dissolution in different diagenetic phases. Quartz overgrowths were important for the maintenance of primary porosity because they sustained the framework, limiting mechanical compaction. The relationship between the main diagenetic constituents and porosity is illustrated in Fig. 11.

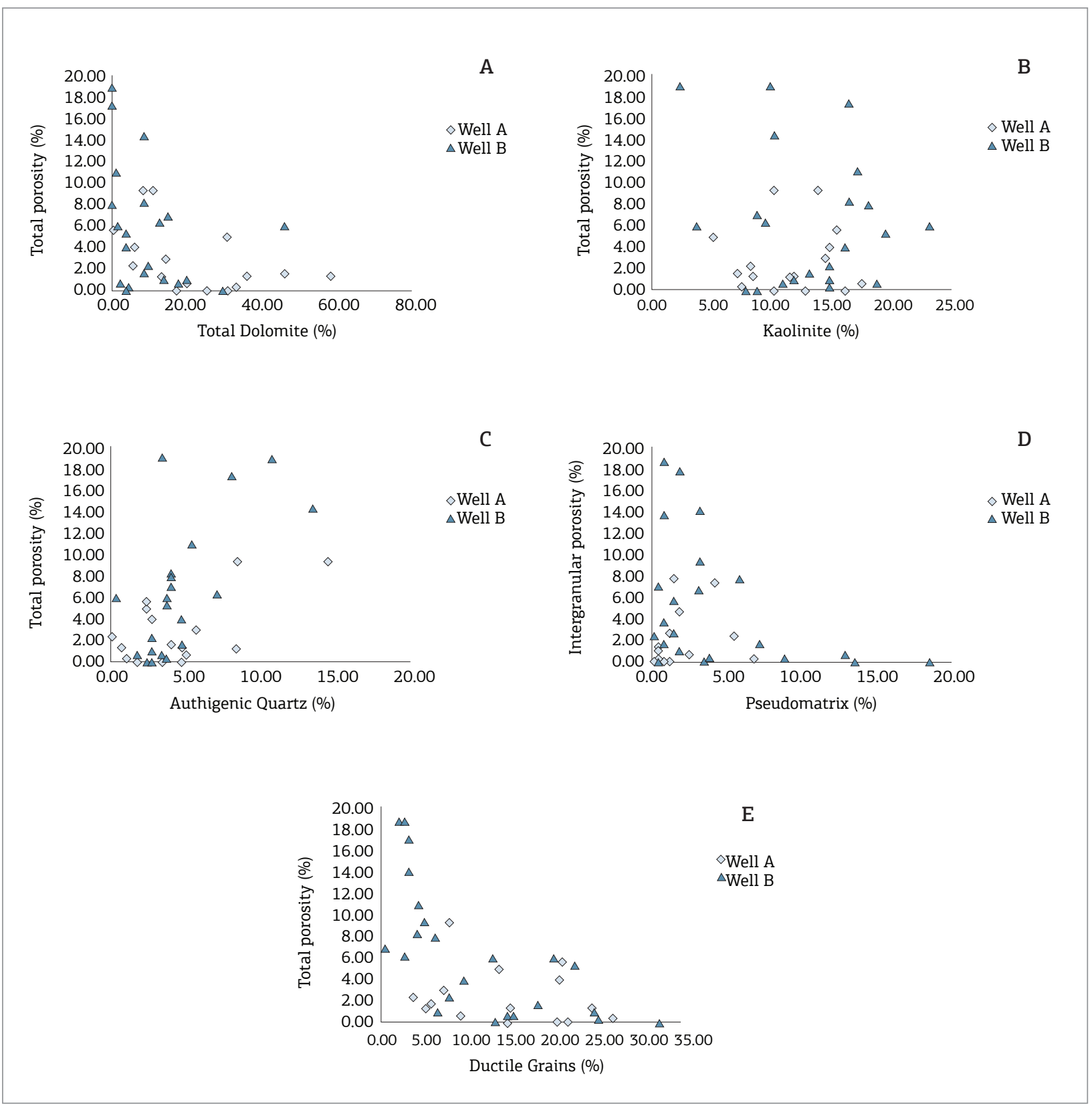

Figure 11. (A) Negative correlation between total porosity and total dolomite for the two studied wells. Dolomite does not interfere significantly with porosity, since it is dominantly substitutive. (B) Relationship between total porosity and kaolinite, showing wide data dispersion. Some samples in Well B present that kaolinite affects negatively the porosity. (C) Relationship between total porosity and authigenic quartz. The presence of quartz overgrowths impact positively on the total porosity. (D) Relationship between total porosity and pseudomatrix. Generation of pseudomatrix had a significant impact in intergranular porosity especially in Well B. (E) Inverse relation between porosity and quantity of ductile grains. 
Fig. 11A shows the inverse relation between total porosity and total dolomite, mainly in Well B. Well A shows dispersion similar to B; however, in some samples, the quantity of dolomite does not significantly interfere with porosity, since dolomite is dominantly substitutive.

In relation to kaolinite and total porosity, there is wide data dispersion (Fig. 11B). This occurs mainly because kaolinite replaces low-grade metamorphic rock fragments, feldspar, micas, and mud intraclasts. Despite the dispersion, some samples in Well B show that kaolinite affects negatively in the total porosity, which may occlude pores and pore throats to variable extents depending on their morphology (Lander \& Bonnell 2010; Morad et al. 2010).

The authigenic quartz (Fig. 11C) has a positive impact on total porosity. The precipitation of quartz overgrowths inhibited mechanical compaction and generation of pseudomatrix that obliterates primary porosity (Bloch et al. 2002).

Pseudomatrix generation had a significant impact on intergranular porosity, especially in Well B (Fig. 11D). This was the main process of primary porosity destruction. There is a strong inverse relation between porosity and quantity of ductile grains (Fig. 11E). These constituents and their diagenetic products (lithic and argillaceous pseudomatrix) are responsible for porosity loss (Pittman \& Larese 1991; Bloch 1994; De Ros 1996), which is evident in Well A, where ductile grains are abundant.

\section{CONCLUSIONS}

The petrographic analyses of 40 thin-sections in two wells located in Atalaia High indicated that:

Wells A and B show subtle differences in detrital composition directly influenced by diagenesis and porosity.

- Diagenetic processes and their products are compaction of metamorphic rock fragments and intraclasts, forming pseudomatrix; quartz and feldspar (albite and K-feldspar) overgrowths and outgrowths; cementation and replacement by kaolinite; precipitation of dolomite and ferrous dolomite to ankerite; pyrite; iron oxides and hydroxides; and titanium diagenetic minerals, in addition to dissolution events in eo-, meso- and telogenesis.

- Reduction of original porosity occurred due to mechanical compaction (through the generation of pseudomatrix) and cementation by kaolinite and dolomite. Preservation of primary porosity was favoured by the presence of quartz overgrowths, especially in Well B.

- Two paragenetic models were constructed for each different detrital composition (litharenites/sublitharenites, and subarkoses). The main difference in the models is the lower intensity of mechanical compaction in subarkoses (Well B) due to the low quantity of ductile grains and abundance of quartz overgrowths. The latter preserve the primary porosity by holding the original framework. Consequently, Well B has the best reservoirs, as a reflection of their composition and better sorting in relation to Well A.

Thirteen reservoir petrofacies were defined based on different compositions and diagenetic patterns. They were grouped in four petrofacies association that represent different reservoir qualities: good-, medium-, and low-quality and non-reservoir. Overall reservoirs have low-quality; however, they are interspersed with medium- and good-quality levels.

\section{ACKNOWLEDGEMENTS}

The authors would like to thank UO-SEAL Petrobras for the access to the studied thin sections and for the permission to publish this work, especially M.Sc. Maria Rosilene Menezes. Special acknowledgements are paid to the support of the Brazilian National Petroleum Agency - ANP (in the form of a fellowship and research funds for A.G. Rodrigues), to Jaques Soares Schmidt and Christiano $\mathrm{Ng}$ for suggestions and final review, and to LHB-Endeeper for access to the Petroledge ${ }^{\circledast}$ software. The authors wish to thank an anonymous reviewer for the pertinent suggestions.

\section{REFERENCES}

Anjos S.M.C., De Ros L.F., Souza R.S., Silva C.M.A., Sombra C.L. 2000. Depositional and diagenetic controls on the reservoir quality of Lower Cretaceous Pendência sandstones, Potiguar rift basin, Brazil. AAPG Bulletin, 84:1719-1742.

Barreiro C.B. 2004. Integração de dados de afloramento, perfis eletrorradioativos e de georadar para análise de análogos aos reservatórios pré-rifte/rifte: um exemplo de aplicação nas formações
Serraria, Barra de Itiúba e Penedo, Bacia de Sergipe-Alagoas. MS Dissertation, Instituto de Geociências, Universidade Federal do Rio Grande do Sul, Porto Alegre, 160 p.

Becker A.P. 1987. Estudo petrológico dos reservatórios da Fm. Barra de Itiúba no Campo de Furado, Bacia de Sergipe Alagoas. MS Dissertation, Instituto de Geociências, Universidade Federal de Ouro Preto, Ouro Preto, 111 p. 
Bjørlykke K., Egeberg P.K. 1993. Quartz cementation in sedimentary basins. AAPG Bulletin, 77:1538-1548.

Bloch S. 1994. Effect of detrital mineral composition on reservoir quality. In: Wilson M.D. (ed.) Reservoir quality assessment and prediction in clastic rocks. Society of Economic Paleontologists and Mineralogists Short Course 30, p. 161-182

Bloch S., Helmond K.P. 1995. Approaches to predicting reservoir quality in sandstones. American Association of Petroleum Geologists Bulletin, 79:97-115.

Bloch S., Lander R.H., Bonell L. 2002. Anomalously high porosity and permeability in deeply buried sandstones reservoirs: origin and predictability. AAPG Bulletin, 86:301-328.

Borba C., Paim P.S.G., Garcia A.J.V. 2011. Estratigrafia dos depósitos iniciais do rifte no Campo de Furado, região de São Miguel dos Campos, Bacia de Sergipe-Alagoas. Revista Brasileira de Geociências, 41(1):18-36

Campos Neto O.P.A., Lima W.S., Gomes Cruz F.E. 2007. Bacia de Sergipe-Alagoas. Boletim de Geociências da Petrobras, 15(2):405-415.

Chiossi D.S.N. 2005. Seqüências deposicionais de $3^{a}$ ordem em riftes continentais: um modelo de tratos de sistemas para grábens assimétricos aplicado ao Cretáceo Inferior da Bacia de Sergipe-Alagoas. Boletim de Geociências da Petrobras, 13(2):181-203.

De Ros L.F. 1996. Compositional controls on sandstone diagenesis. Comprehensive summaries of Uppsala dissertations from the Faculty of Science and Technology, 198:1-24.

De Ros L.F., Golberg K., Abel M., Victoreti F., Mastella M., Castro E. 2007. Advanced acquisition and management of petrographic information from reservoir rocks using the Petroledge ${ }^{\circledR}$ System. In: AAPG Annual Convention and Exhibition, Long Beach, Expanded Abstracts.

De Ros L.F., Goldberg K. 2007. Reservoir petrofacies: a tool for quality characterization and prediction. In: AAPG, Annual Convention and Exhibition, Long Beach, Abstracts Volume, p. 1.

Dickinson W.R. 1985. Interpreting provenance relations from detrital modes of sandstones. In: Zuffa G.G. (ed.) Provenance of Arenites. The Netherlands, NATO-ASI Series C. D. Reidel Pub. Co., Dordrecht, 148, p. 333-361.

Ehrenberg S.N. 1989. Assessing the relative importance of compaction processes and cementation to reduction of porosity in sandstones: discussion; compaction and porosity evolution of Pliocene sandstones, Ventura Basin, California: discussion. American Association of Petroleum Geologists Bulletin, 73(10):1274-1276

Feijó F.J. 1994. Bacias de Sergipe e Alagoas. Boletim de Geociências da Petrobras, 8(1):149-160.

Folk R.L. 1968. Petrology of sedimentary rocks. Austin, Hemphill's, 182 p.

Galm P.C., Santos D.F. 1994. Caracterização de uma discordância de idade Pré-Aratu (Eocretáceo) na Bacia de Sergipe-Alagoas. Acta Geológica Leopoldensia, 39(2):555-562

Garcia A.J.V., De Ros L.F., Souza R.S., Bruhn C.H.L. 1990. Potencial de reservatórios profundos na Formação Serraria, Bacia de Sergipe-Alagoas. Boletim de Geociências da Petrobras, 4(4):467-488

Giles M.R., Indrelid S.L., Beynon G.V., Amthor J. 2000. The origin of large-scale quartz cementation: Evidence from large data sets and coupled heat-fluid mass transport modeling. In:
Worden R.H., Morad S. (eds.) Quartz cementation in sandstones. International Association of Sedimentologists Special Publication, 29, p. 21-38

Ketzer J.M., Morad S., Amorosi A. 2003. Predictive diagenetic clay-mineral distribution in siliciclastic rocks within a sequence stratigraphic framework. In: Worden R.H., Morad S. (eds.) Clay Mineral Cements in Sandstones. International Association of Sedimentologists Special Publication 34, Oxford, Blackwell Science, p. 42-59

Lander R.H., Bonnell L.M. 2010. A model for fibrous illite nucleation and growth in sandstones. AAPG Bulletin 94:1161-1187.

Luo J., Hlal O., Morad S., Ketzer J.M. 2009. Diagenetic and reservoir-quality evolution of fluvial and lacustrine deltaic sandstones: Evidence from Jurassic and Triassic sandstones of the Ordos Basin, northwestern China. Journal of Petroleum Geology, 32:79-102

Machel H.G. 1987. Some aspects of diagenetic sulphatehydrocarbon redox reactions. In: Marshall J.D. (ed.) Diagenesis of Sedimentary Sequences. Geological Society (London) Special Publication 36, Oxford, Blackwell Scientific, p. 15-28.

McBride E.F. 1989. Quartz cementation in sandstones - a review. Earth-science Reviews, 26:69-112

Milliken K.L. 2005. Late Diagenesis and Mass Transfer in Sandstone-Shale Sequences. In: Mackenzie F.T. (ed.) Sediments, Diagenesis, and Sedimentary Rocks. Oxford, Elsevier, UK, p. 159-190.

Morad S., Bergan M., Knarud R., Nystuen J.P. 1990. Albitization of detrital plagioclase in Triassic reservoir sandstones from Snorre Field, Norwegian North Sea. Journal of Sedimentary Petrology, 60(3):411-425

Morad S., Ketzer J.M., De Ros L.F. 2000. Spatial and temporal distribution of diagenetic alterations in siliciclastic rocks: implications for mass transfer in sedimentary basins. Sedimentology, 47(1):95-120

Morad S., Al-Ramadan K., Ketzer J.M., De Ros L.F. 2010. The impact of diagenesis on the heterogeneity of sandstone reservoirs: A review of the role of depositional facies and sequence stratigraphy. AAPG Bulletin, 94(8):1267-1309.

Moraes Rego L.F. 1933. Notas sobre a geologia, a geomorfologia e os recursos minerais de Sergipe. Anais da Escola de Minas de Ouro Preto, 24:31-84

Pitman J.K., Anders D.E., Fouch T.D., Nichols D.J. 1986. Hydrocarbon potential of nonmarine Upper Cretaceous and Lower Tertiary Rocks, eastern Uinta Basin, Utah. In: Spencer R.W., Mast R.F. (eds.) Geology of tight gas reservoirs. AAPG Studies in Geology, 24:235-252

Pittman E.D., Larese R.E. 1991. Compaction of lithic sands Experimental results and applications. AAPG Bulletin, 75:1279-1299.

Saigal G.C., Morad S., Bjørlykke K., Egeberg P.K., Aagaard P. 1988. Diagenetic albitization of detrital K-feldspars in Jurassic, Lower Cretaceous, and Tertiary clastic reservoirs from offshore Norway, I. Textures and origin. Journal of Sedimentary Petrology. 58:1003-1013.

Schaller H. 1969. Revisão estratigráfica da Bacia SergipeAlagoas. Boletim Técnico da Petrobras, 12(1):21-86. 
Silva F.M.A., Santana A.C., Bonfim L.F.C. 1978. Evolução tectono-sedimentar do Grupo Estância: suas correlações. In: 30 Congresso Brasileiro de Geologia, Recife, Anais, v. 2, p. 685-699.

Souza R.S., De Ros L.F., Morad S. 1995. Dolomite diagenesis and porosity preservation in lithic reservoirs: Carmópolis Member, Sergipe- Alagoas Basin, Northeastern Brazil. AAPG Bulletin, 79(5):725-748

Tucker M.E. 1988. Techniques in Sedimentology. Oxford, Blackwell Science Publishing, 391 p.
Worden R.H., Burley S.D. 2003. Sandstone diagenesis: the evolution of sand to stone. In: Burley S.D., Worden R.H. (eds.) Sandstone diagenesis: recent and ancient. Reprint Series of the International Association of Sedimentologists, New York, Blackwell Publishing Ltd., p. 3-44.

Zuffa G.G. 1985. Optical analyses of arenites: influence of methodology on compositional results. In: Zuffa G.G. (ed.) Provenance of Arenites. NATO-ASI Series C. D. Reidel Pub. Co., 148, Dordrecht, The Netherlands, p. 165-168.

Arquivo digital disponível on-line no site www.sbgeo.org.br 